\title{
SPANISH AND ENGLISH CONTACT AND MORPHEME ACQUISITION
}

\section{EL CONTACTO ESPAÑOL INGLÉS Y LA ADQUISICIÓN DE MORFEMAS}

\section{Daniel J. Smith}

Clemson University

\begin{abstract}
Regarding the order of morpheme acquisition in both first language (L1) and second language (L2) acquisiton there appears to be a socalled 'natural order' of acquisition. In addition, there are peculiarities which are part of the morphosyntax of any language influencing the order of morpheme acquisition in $L 2$, whether it be from the $L 1$, or as in the case of simultaneous bilinguals, another L1. We use Myers-Scotton's (2002) 4-M model to help us analyze and discuss the data. The analysis shows a tendency for speakers to acquire language morphology in a natural order, regardless of the $L 1$, but with special reference to Spanish and English we show that the two languages can influence each other and make changes in the order of acquisition.
\end{abstract}

KEYWORDS: bilingualism, language acquisition, interference, convergence, morpheme acquisition
RESUMEN: En la secuencia de la adquisición de morfemas en la primara lengua (L1) y en la segunda lengua (L2) parece haber una 'secuencia natural' de adquisición. Además, hay diferencias que son parte de la morfosintaxis de cualquier lengua que puedan cambiar este orden de adquisición en la $L 2$, que sea de la $L 1$, o como en el caso del bilingüismo simultáneo, de la otra L1. Usamos el modelo 4-M de Myers-Scotton (2002) para ayudarnos a analizar y considerar los datos. El análisis muestra la tendencia de que haya una secuencia natural en cualquier L1, pero con una referencia especial al español y al inglés mostramos que las dos lenguas pueden influirse y que esto puede cambiar la secuencia de la adquisición.

PALABRAS CLAVE: bilingüismo, adquisición de lenguas, interferencia, convergencia, adquisición de morfema 


\section{$1 \quad$ INTRODUCTION}

The study of the order of morpheme acquisition has shown that languages share a natural order of morpheme acquisition. However, the differences in languages must also be taken into account. A first language acquired (Language 1 or L1) can influence the acquisition of a second language (Language 2 or L2). This study attempts to understand a universal order of morpheme acquisition but with variations from specific language interference, with special reference to the acquisition of English and Spanish.

\section{THE ORDER OF ACQUISITION IN L1 AND L2}

Roger Brown (1973) found that children learning English as L1 learned the types of morphemes in a fixed order. This claim soon became the 'natural order' of acquisition, a claim made by Dulay and Burt (1974).

This was applied to L2 acquisition by Krashen (1982) and Krashen and Terrell (1983); they claimed that "By allowing student errors to occur without undue emphasis on error correction, the...teacher allows the nautral order to take its course" and that morphemes such as the third person singular $s$ on verbs in English or gender agreement morphemes on adjectives in Spanish, for example, are not expected to be acquired as early as other morphemes (Krashen and Terrell 1983: 59).

Some researchers made the claim that the order of morpheme acquisition in L2 was not influenced significantly by L1. For example, Dulay and Burt (1974) reported research that found that children whose first language was Spanish, Chinese, Japanese, or Norwegian showed the same acquisition of English morphosyntax.

However, Luk and Shirai (2009) have found that this is not always the case. They found that what was purported to be a natural order of acquisition, regardless of the L1, at least sometimes varies depending on which language is the L1. They found that L1 Spanish speakers learning L2 English had a different $L 2$ acquisition order than $L 1$ Japanese, Chinese, and Korean speakers learning $L 2$ English.

L2 research has emphasized L2 acquisition of English. One very obvious problem with making too many assumptions based on $\mathrm{L} 2$ acquisiton of English is that English lacks many system morphemes that some other languages, such as Spanish, have.

\section{THE 4-M MODEL}

The 4-Morpheme model (4-M model) (Myers-Scotton 2002) is a useful way to help us understand the order of acquisition of morphemes. The 4-M model is a classification of all morphemes of all languages into four groups:

-content morphemes and three different types of system morphemes

-early system morphemes and -late bridge system morphemes

Normas (ISSN: 2174-7245) |

https://ojs.uv.es/index.php/normas/index

Diciembre 2017 | Volumen 7 | Número 2 | Pág.298 
-late outsider system morphemes

(1) Dogs run. John's dog gallops.

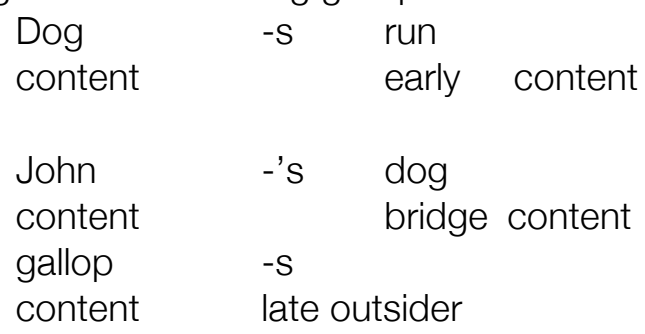

- Content morphemes carry the crucial content of the utterance (e.g. dog, run). Content morphemes assign or receive thematic roles.

- System morphemes neither assign nor receive thematic roles. Nouns, adjectives, and verbs without gender, person, and number affixes, are content morphemes.

- An early system morpheme adds to the meaning of a content morpheme within the immediate phrase of a content morpheme, for example inside a Noun Phrase (NP).

(2) Example: plural -s on nouns in English dog $-\mathrm{s}$

A late bridge system morpheme does not change or add to the meaning of a content morpheme but sometimes connects two content morphemes into a larger relationship, thus the name 'bridge'. Omitting the bridge morpheme, however, does not detract from the meaning.

(3) Example: possessive -'s in English John's dog

A late outsider system morpheme points to a content morpheme outside its own immediate phrase.

(4) Example: 1st person singular -s on verbs makes reference to the content morpheme which is the subject of the verb, not to the verb itself. The dog run-s

Example (5) is a sentence in Spanish illustrating each type of morpheme in the 4-M model (Smith 2013:31,34):

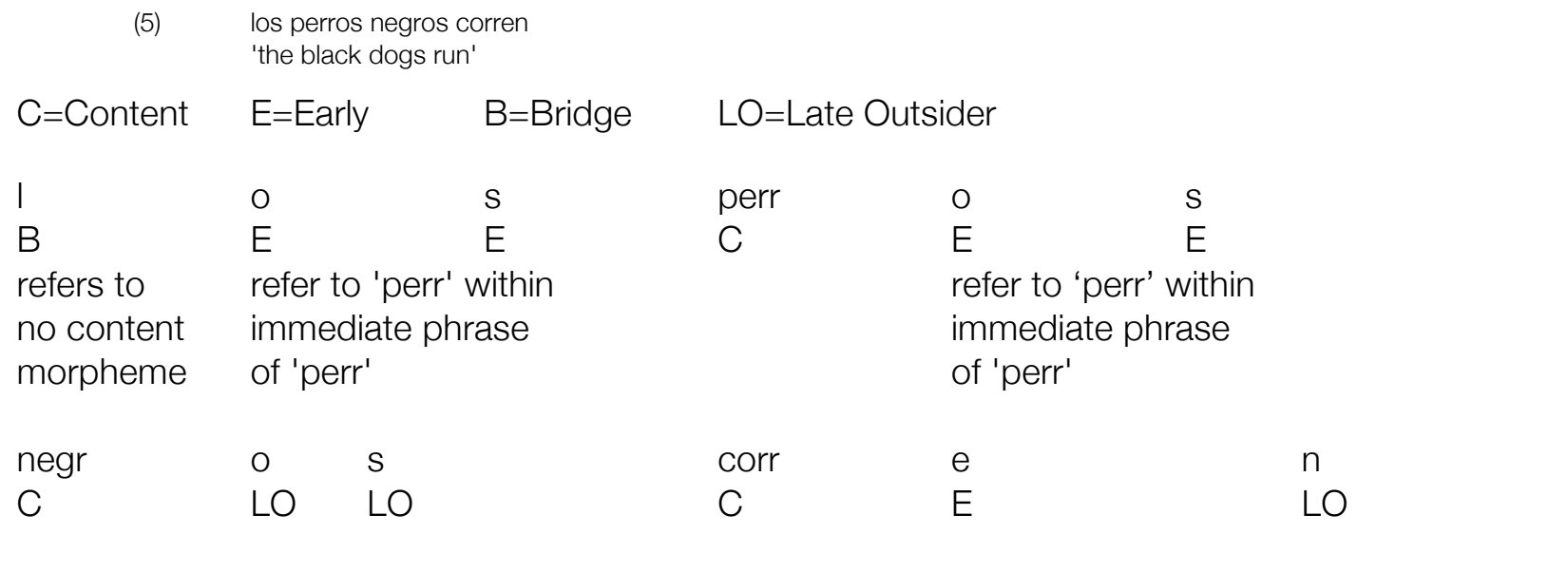


refer to 'perr' outside

immediate phrase of 'negr' refers to

'corr' within

immediate

phrase of refers to

'perr' outside immediate

phrase of 'corr'

'corr'

\section{APPLYING THE 4-M MODEL TO L1 AND L2 ACQUISITION}

Applying the 4-M model to Brown's (1973) study of L1 acquisiton of English, morphemes seem to acquired in the following order: content; early system morphemes, plural -s on nouns; late bridge system morphemes, possessive -s on nouns; and finally late outsider system morphemes, the third person singular -s on verbs. Longxing Wei (2000a,b) showed L2 data evidence for content morphemes being acquired before early system morphemes and early system morphemes being acquired before late system morphemes. His data were language samples of $L 2$ English learners who were L1 speakers of Chinese and Japanese.

Comparing two L1 English speakers learning L2 Spanish, Smith (2013) found that the more advanced L2 student had a higher percentage of errors in the late system morpheme category, providing further support for the order of acquisition being content, followed by early system morphemes and finally late system morphemes.

\section{CONVERGENCE, SIMPLIFICATION, AND INTERFERENCE}

Myers-Scotton (2002) states that there is a 'composite' template ${ }^{1}$ or pattern for sentence structure, a combination of grammatical patterns from both languages. This template is a construct within the brain and cannot automatically be assumed to relate to only one language's grammatical patterns. Examples (6-11) are utterances of children between seven and twelve years of age in a Hispanic community in northeast Georgia, U.S.A. The community is large but there is extensive contact with English, especially for children in the English language instruction schools.

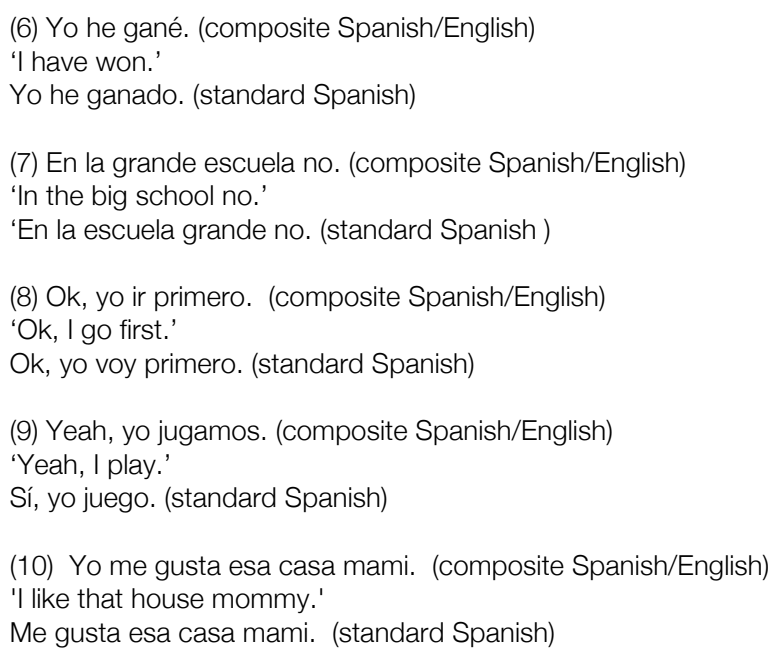

${ }^{1}$ Myers-Scotton (2002) calls this 'composite' template a 'composite Matrix Language Frame'. The 'Matrix Language Frame' model (MLF model) is another model complemented by the 4-M model in her theory.

Normas (ISSN: 2174-7245) | 
(11) I no can see. (composite English/Spanish)

I cannot see. (standard English)

Smith (2004:168-169) has argued that the examples of convergence above are not just simplification or lack of acquisition of some morphemes due to incomplete acquisition by children. For example, English lacks several of the late sytem morphemes on verbs that Spanish has. In example (6) above, two Spanish verb forms 'gané' and 'ganado' are used for one verb form 'won' in English; it is easy for children acquiring both English and Spanish before either language is full acquired to confuse the two Spanish forms since English uses the same word for both. Some of the convergence examples above were uttered by a child at least ten years old and very similar patterns were found in the speech of at least three other children who were relatively isolated from other Hispanics except their parents and who were exposed to large amounts of English at school, where English was the main if not the only means of instruction. In comparison, there were children ten years of age and younger in other areas of the same Hipanic community who also attended English-speaking schools but were not isolated from other Hispanic children but rather had frequent contact with other Hispanic children inside and outside of school. Their utterances showed much more conformity to standard Spanish morphosyntactic patterns, including the late system morphemes on verbs and adjectives that Spanish has which English lacks. Therefore, the heavier contact with English and isolation from other Spanish-speaking children of the first group is likely to be the contributing factor to the difference between the two groups of children.

\section{DISTINGUISING THE NATURAL ORDER OF ACQUISITION FROM INTERFERENCE/CONVERGENCE}

Since Spanish has more system morphemes, especially late outsider (LO) system morphemes, the learner simply omits or chooses the wrong one of a menu of morphemes which English does not provide, playing as if it were a game of 'hit or miss'. Speakers' omitting these late system morphemes follows to an extent the natural order of acquisition, since the greatest number of errors made are those system morphemes last to be acquired by learners of any language. The fact that English lacks these morphemes is matched by $L 1$ learners of any language omitting these system morphemes in their speech.

Sometimes a specific word or morpheme is chosen by analogy with English ('gané' for 'ganado'). This cannot be relegated entirely to the natural order of acquisition, but to specific interference, or language contact, because of all the possible forms of the verb 'ganar', 'gané' was the one chosen. Another illustration of the influence of English is the use of the word 'yo' in example (10) when not required at all in Spanish, when it could more easily have been omitted as is the norm in Spanish.

\section{CONCLUSIONS AND IMPLICATIONS FOR FURTHER RESEARCH AND L2 INSTRUCTION}

The 'natural order of acquisition' is not always the same, but complicated by which language is $L 1$, which language is $L 2$, and further complicated by simultaneous acquisition of both. In some cases, as we have seen for example with children growing up with Hispanic parents where communication is in Spanish at home and virtually all their other language exposure is in English outside of the home, it is difficult to tell which is L1 and which is L2. In simultaneous bilingualism, both languages are L1 and there is no L2. We have shown that children growing up as simultaneous bilinguals or in a situation approaching simultaneous bilingualism are very likely to have at least one of the languages heavily affected by the other, and what would have been a 'natural order of acquisition' is not the 
same as for other children the same age whose langauge is not equally affected by the other language.

Futher research is needed to continue to untangle the complications, and especially those of simultaneous bilingualism and language interference and convergence.

L1 and L2 instructors should be aware of some of the tendencies toward a natural order of acquisition, but also aware of the specific interference patterns of the first language impacting the second language or both languages in simultaneous bilingualism. This should lead to instruction not only geared to communicative competence but also to grammatical accuracy. The implications are obvious for L2 English language instructors or L2 Spanish language instructors.

\section{REFERENCES}

Brown, Roger (1973): A first language: The early stages. Cambridge, MA: Harvard University Press.

Dulay, Heidi C. \& Marina K. Burt (1974): "Natural sequences in child second language acquisition", Language Learning 24(1), 37-53.

Krashen, Stephen D. (1982): Principles and Practice in Second Language Acquisition. Oxford: Pergamon Press.

Krashen, Stephen D. \& Tracy D. Terrell (1983): The Natural Approach: Language Acquisition in the Classroom, London: Prentice Hall Europe.

Luk, Zoe Pei-sui \& Yasuhiro Shirai (2009): "Is the acquisition order of grammatical morphemes impervious to L1 knowledge?: Evidence from the acquisition of plural -s, articles, add possessive 's", Language Learning 59(4),721-754.

Myers-Scotton, Carol (2002): Contact Linguistics: Bilingual Encounters and Grammatical Outcomes. Oxford University Press.

Smith, Daniel J. (2004): "Spanish influenced by English in Georgia: Intra-speaker variation", Southwest Journal of Linguistics, 23(2), 163-185.

Smith, Daniel J. \& Manuel Morales (2013): "Second language acquisition of Spanish by morpheme type: The 4-M model", Southern Journal of Linguistics 37(1), 28-45.

Wei, Longxing (2000a): "Types of morphemes and their implications for second language morpheme acquisition", International Journal of Bilingualism 4(1), 29-43.

Wei, Longxing (2000b): "Unequal election of morphemes in adult second language acquistion" Applied Linguistics 21(1), 106-140.

Normas (ISSN: 2174-7245) | 